\title{
19. THE CORK EXPERIMENT IN HOLE 949C: LONG-TERM OBSERVATIONS OF PRESSURE AND TEMPERATURE IN THE BARBADOS ACCRETIONARY PRISM ${ }^{1}$
}

\author{
K. Becker, ${ }^{2}$ A.T. Fisher, ${ }^{3}$ and E.E. Davis ${ }^{4}$
}

\begin{abstract}
At the end of Leg 156, Hole 949C was sealed and a CORK (circulation obviation retrofit kit) was installed for long-term monitoring of temperatures and pressures to study the hydrology of the Barbados accretionary prism. The hole was completely cased except for a 53-m perforated and screened section spanning the décollement, so that CORK pressures should reflect hydrologic conditions in the décollement. Nearly a year and a half after beginning the experiment, a 512-day record was obtained by using the submersible Nautile. The temperature data define a linear gradient consistent with the $82^{\circ} \mathrm{C} / \mathrm{km}$ gradient determined during Leg 156, and they show no evidence of transients caused by fluid flow. Pressures in the décollement stabilized after 250 days at a value of $1.02 \mathrm{MPa}$ above hydrostatic, less than one-third of the overburden pressure. At this fluid pressure value, there should be little enhancement of permeability along the décollement, and the pressure data show little evidence for the transient flow processes thought to dominate the hydrology of fine-grained accretionary prisms like those off Barbados. A step-wise increase of pressure from $0.9 \mathrm{MPa}$ to the stable value of $1.02 \mathrm{MPa}$ was observed from 170 to 250 days, and this might be interpreted as a minor fluid-flow event. The tidal loading signal was recorded in the sealed hole attenuated to about $85 \%$ of the seafloor level, with a phase lag of about $15 \mathrm{~min}$. The attenuation value is consistent with the high porosity of the muddy sediments $(\sim 60 \%)$. The phase lag requires a contrast in the bulk moduli of the sediments in the décollement as opposed to those above or below the décollement, consistent with its seismic signature and its nature as a plate boundary fault. The CORK experiment continues to function in Hole 949C and should provide further data through 1997.
\end{abstract}

\section{INTRODUCTION}

A major objective of drilling at accretionary complexes has been to document the role of fluids and fluid pressures in the deformational and geochemical processes occurring at subduction zone plate boundaries. Fluid pressures have long been known to be a critical factor in the behavior of faults, with high fluid pressures reducing the strength of and resistance to motion along faults (e.g., Hubbert and Rubey, 1959). Also, it is now recognized that an important component of global geochemical cycling occurs through transport of chemical constituents in fluids expelled from the subducted plate, as well as accretionary prisms, by compaction and deformation. The flow of these fluids is thought to be episodic and largely controlled by permeability along the complex of faults and fractures in accretionary prisms (e.g., Vrolijk et al., 1991; Knipe et al., 1991; Davis et al., 1995). The fault- and fracture-permeability in accretionary complexes is itself probably dependent on fluid pressure (e.g., Screaton et al., 1995; Fisher and Zwart, Chapter 15, this volume); as fluid pressures in faults increase towards lithostatic pressures, the effective permeabilities of these faults may increase by orders of magnitude. Understanding tectonic and fluid-flow processes at accretionary prisms thus requires documenting the inter-relationships between these processes and fluid pressures. The polarities of seismic reflections are sensitive to fluid pressures in major fault zones such as the décollement in the Barbados accretionary prism (e.g., Shipley et al., 1994; Bangs et al., 1996), but only drilling provides the hope of directly determining these fluid pressures to substantiate our understanding of

${ }^{1}$ Shipley, T.H., Ogawa, Y., Blum, P., and Bahr, J.M. (Eds.), 1997. Proc. ODP, Sci. Results, 156: College Station, TX (Ocean Drilling Program).

${ }^{2}$ Rosenstiel School of Marine and Atmospheric Science, University of Miami, 4600 Rickenbacker Causeway, Miami, FL 33149, U.S.A.

${ }^{3}$ Earth Sciences Department, University of California, Santa Cruz, CA 95064, U.S.A

${ }^{4}$ Pacific Geoscience Centre, Geological Survey of Canada, P.O. Box 6000, Sidney, British Columbia V8L 4B2, Canada. fluid and tectonic processes. Unfortunately, the nature of the drilling method - requiring extensive circulation of drilling fluids and mudvirtually precludes accurate determination of in situ fluid pressures at the time of drilling. Instead, long-term experiments are required, to allow recovery of both borehole and nearby formation pressures from the drilling disturbance and then to accurately document fluid pressures in fault zones.

In June-July of 1994, Leg 156 of the Ocean Drilling Program (ODP) embarked on a focused study of the role of fluid pressures and episodic fluid flow in the Barbados accretionary prism, utilizing a range of innovative experiments and new techniques (Shipley, Ogawa, Blum, et al., 1995). Critical to this effort was deploying instrumented borehole seals (or CORKs, Davis et al., 1992) in two reentry holes drilled across the décollement at the base of the accretionary prism. The two CORK experiments were designed to obtain longterm $(2-3 \mathrm{yr})$ records of temperatures and pressures in the sealed holes, both to determine background in situ conditions along the décollement and to monitor for signs of the episodic fluid-flow events that are now inferred to dominate the active hydrology of accretionary prisms. Three sites were drilled during Leg 156 (Fig. 1; Shipley, Ogawa, Blum, et al., 1995), carefully located with respect to very detailed seismic images of the décollement. These images show distinct regions of positive and negative polarity of the décollement reflector, suggesting spatial variability in fluid pressures in and below the décollement (Shipley et al., 1994; Bangs et al., 1996). Sites 947 and 949 are located where the polarity of the décollement reflection is negative, suggesting high fluid pressures in the décollement. Site 948 is located in an area of positive polarity seismic reflection at the décollement. Results of logging while drilling (LWD) at Sites 947 and 948 (Moore et al., 1995) as well as packer tests at Sites 948 and 949 (Fisher and Zwart, Chapter 15, this volume) suggest that high fluid pressures of varying magnitude may exist all along the décollement. Direct measurement of these fluid pressures, after recovery of borehole pressures from drilling disturbances, was an important goal of the CORK experiments deployed in Holes 948D and 949C. In addition, temperature measurements through the décollement are important to 

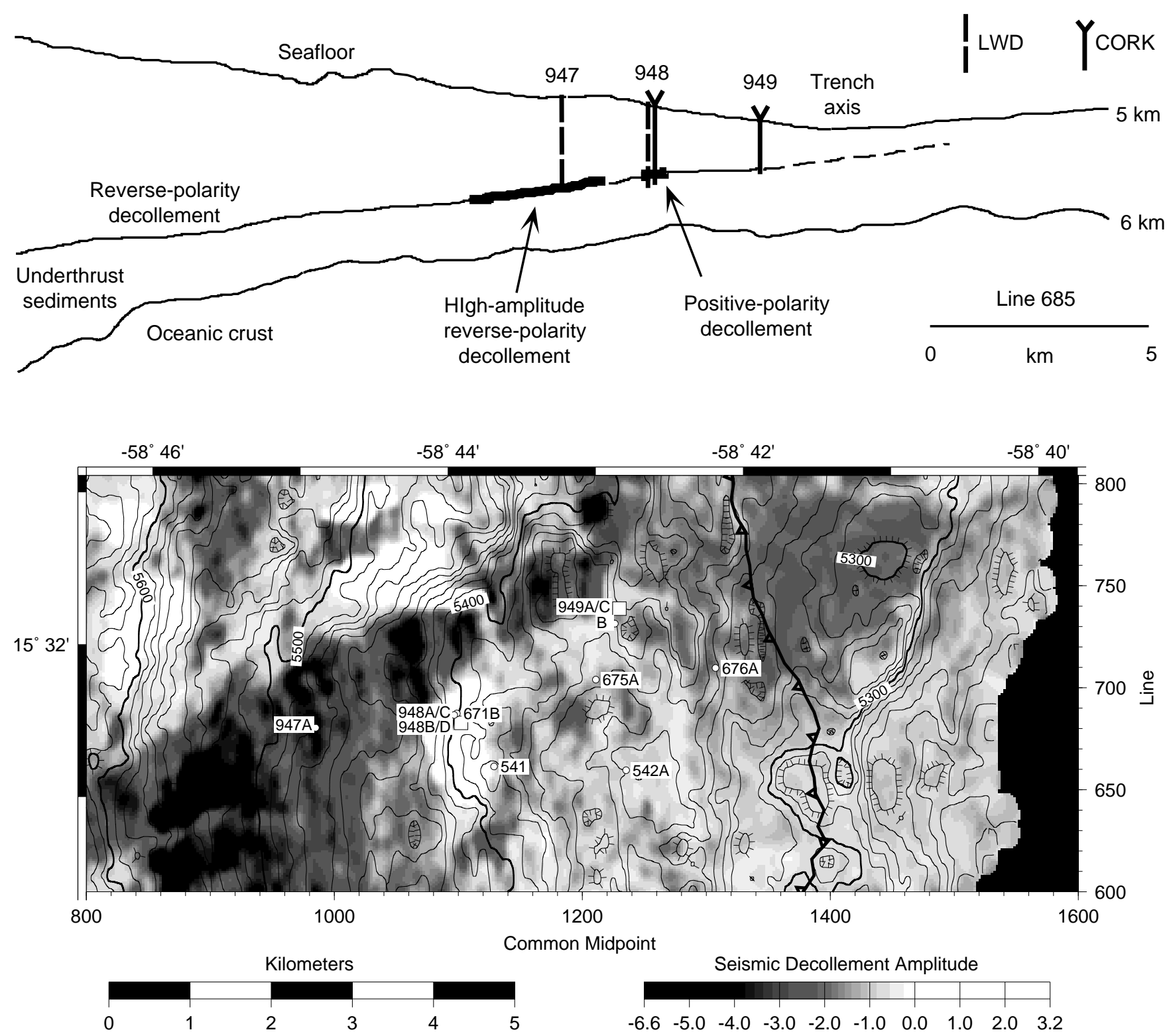

Figure 1. Top: Schematic of Leg 156 drilling program plotted on a line drawing based on a seismic section across the Barbados accretionary prism, showing the intervals studied with LWD and the CORK experiments. Bottom: Locations of sites from Legs 78B, 110, and 156 plotted on a map of depth to the décollement (in $\mathrm{m}$ below sea level) and amplitude of the décollement reflector.

document thermal effects associated with any episodic fluid flow along the décollement.

In December of 1995, French and American scientists conducted the "ODPNaut" expedition, a joint Nautile submersible cruise to the Barbados CORKs supported by IFREMER and NSF. During this cruise the long-term data from both CORKs were successfully recovered nearly $1 \frac{1}{2} \mathrm{yr}$ after their deployment. We report here the results from Hole 949C; a companion paper by Foucher et al. (Chapter 18, this volume) describes the results from the similar experiment in nearby Hole 948D. The results from Hole 949C may represent the first accurate, direct measurement of significant overpressure along the décollement - the major plate boundary fault at the base of an accretionary prism.

\section{CONFIGURATION OF THE CORK EXPERIMENT IN HOLE 949C}

The CORK long-term borehole observatory (described in detail by Davis et al., 1992) includes a hydrologic seal at the seafloor that prevents fluids from passing into or out of the formation via the drill hole. In a hole left filled with seawater, it allows pressure in the hole beneath the seal to equilibrate with that within the formation spanned by either perforated casing or the open hole beneath cemented-in casing. The instrumentation deployed beneath the seal in Hole 949C allows monitoring of temperatures of 10 thermistors on a cable hanging in the hole, pressure just below the seal, and a reference hydrostatic 
pressure just above the seal. Temperatures, pressures, and other parameters are logged at a programmable interval (in this case $1 \mathrm{hr}$ ) for periods of up to three years. Data can be retrieved by submersible or remotely operated vehicle via an underwater-connectable data port at the seafloor installation.

For the CORK experiment at Hole 949C (Fig. 2), the sensor string was deployed down to a depth of $410 \mathrm{~m}$ below seafloor (mbsf), and it included a modular fluid sampler driven by an osmotic pump attached to the string at $260 \mathrm{mbsf}$. (The fluid sampler was attached at such a shallow depth to avoid the twice-folded section at the bottom of the cable, required for operational reasons described below.) Before deploying the sensor string, the hole was cased from seafloor through the décollement, as defined by its seismic signature. This signature is not particularly clear at the site, where the décollement is identified with two reflectors about $0.05 \mathrm{~s}$ apart. The upper reflector is weakly negative in polarity (Shipboard Scientific Party, 1995; Moore et al., Chapter 20, this volume). A 53-m section of the perforated and screened casing was emplaced at 398-451 mbsf, with the intent of spanning the two reflectors and intervening formation. Below this, a bridge plug was installed to seal the base of the cased hole. Thus, the casing was constructed to allow hydrologic communication between the instrumented hole and the décollement, and the CORK

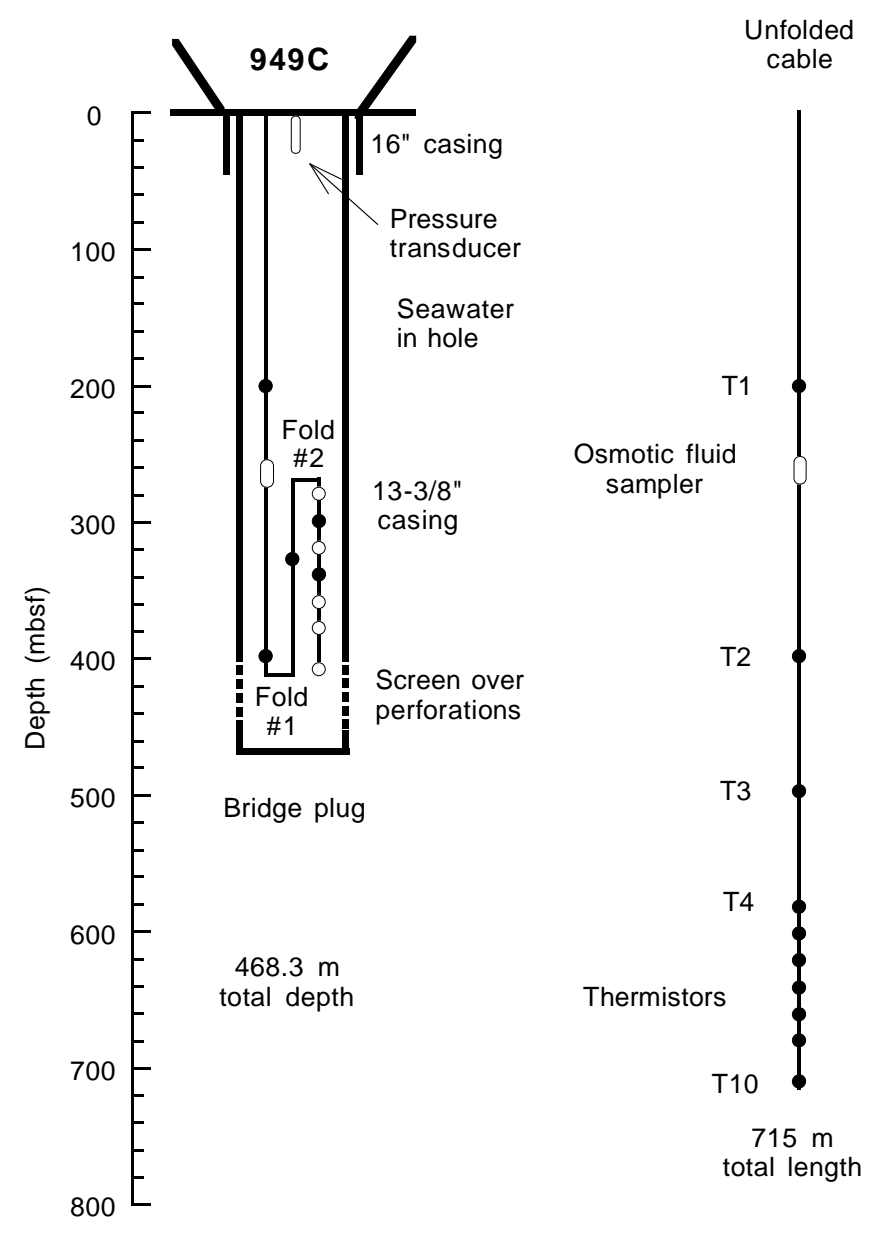

Figure 2. Configuration of the CORK and sensor string deployed during Leg 156 in Hole 949C. Solid circles denote thermistors which yielded good readings; open circles denote thermistors which apparently failed because of conductor damage at the lower fold in the cable. experiment was designed to directly monitor fluid conditions in the décollement. Interpretation of the VSP data (Moore et al., Chapter 20, this volume) suggests that the bottom of the screened interval clearly includes the lower reflector, whereas the top of the screened interval coincides closely with the onset of the upper reflector, perhaps too closely to be fully confident that the screened interval completely includes the entire décollement defined by the pair of seismic events.

Hole preparation and deployment of the CORK experiment were very difficult, as is described in detail by the Shipboard Scientific Party (1995). Hole conditions were poor and numerous operational problems were encountered in deploying both the casing and the CORK experiment. The operational problems included an aborted initial attempt to deploy a sensor string in the hole, resulting in severe damage to that string. This apparently resulted from formation flow through the perforated and screened casing and/or settling of suspended sediment when circulation was stopped, shortening the depth of open hole to less than the length of the cable. In a heroic effort by the entire shipboard party, the replacement sensor string shown in Figure 2 was successfully deployed during the waning moments of Leg 156. The cable had been designed for a 715-m-deep hole and was folded twice, as shown, to avoid the collapsing hole conditions yet still place the thermistors as close as possible to the décollement.

Despite the poor hole conditions, the hole was filled not with mud (as Hole 948D had been) but with seawater, a more desirable condition for both the CORK pressure measurements as well as the fluid sampler. Once the seawater-filled hole thermally re-equilibrated, the pressure excess (relative to hydrostatic) measured immediately below the seal (Fig. 2) reflects the pressure excess at the screened décollement relative to hydrostatic at that depth.

\section{RESULTS Temperatures}

Of the ten thermistors, three were known to have failed at the time of deployment and two more failed shortly thereafter. The data at the times of failure suggest electrical shorts to seawater as the cause. That all five of the faulty thermistors were below the second fold in the cable (Fig. 2) circumstantially suggests that the failure was caused by conductor damage at the fold. This fold was made without a thimble, whereas, at the first fold, a thimble was indeed used to hang off the sinker bar.

Figure $3 \mathrm{~A}$ shows the long-term record of temperatures recorded in Hole 949C by the five valid thermistors. These are T1, T2, T3, T5, and $\mathrm{T} 7$ as denoted in Figure 2, fortuitously spanning the entire measurement interval and including T2 very close to the décollement. The temperature records for these thermistors are all similar in character, showing very smooth recovery curves towards stable apparent equilibrium values. The only departures from smooth, monotonic recovery curves are occasional noise and a slight drop in the value of $\mathrm{T} 1$ at about 300 days, for which no clear cause can be assigned. When plotted against depth (Fig. 4), the apparent equilibrium temperatures are very consistent with the values determined with the water-sampling temperature and pressure tool (WSTP) in nearby Hole 949B during Leg 156 (Shipboard Scientific Party, 1995). The two data sets document a constant, linear gradient of $82^{\circ} \mathrm{C} / \mathrm{km}$ in the interval 200 500 mbsf spanning the décollement and show no evidence for any thermal transients resulting from fluid flow during the experiment thus far.

\section{Pressures}

Figure $3 \mathrm{~B}$ shows that the pressure in the seawater-filled Hole 949C equilibrated to a value of $1.02 \mathrm{MPa}$ above hydrostatic; this confirms the seismic indication of moderately high fluid pressure at the 

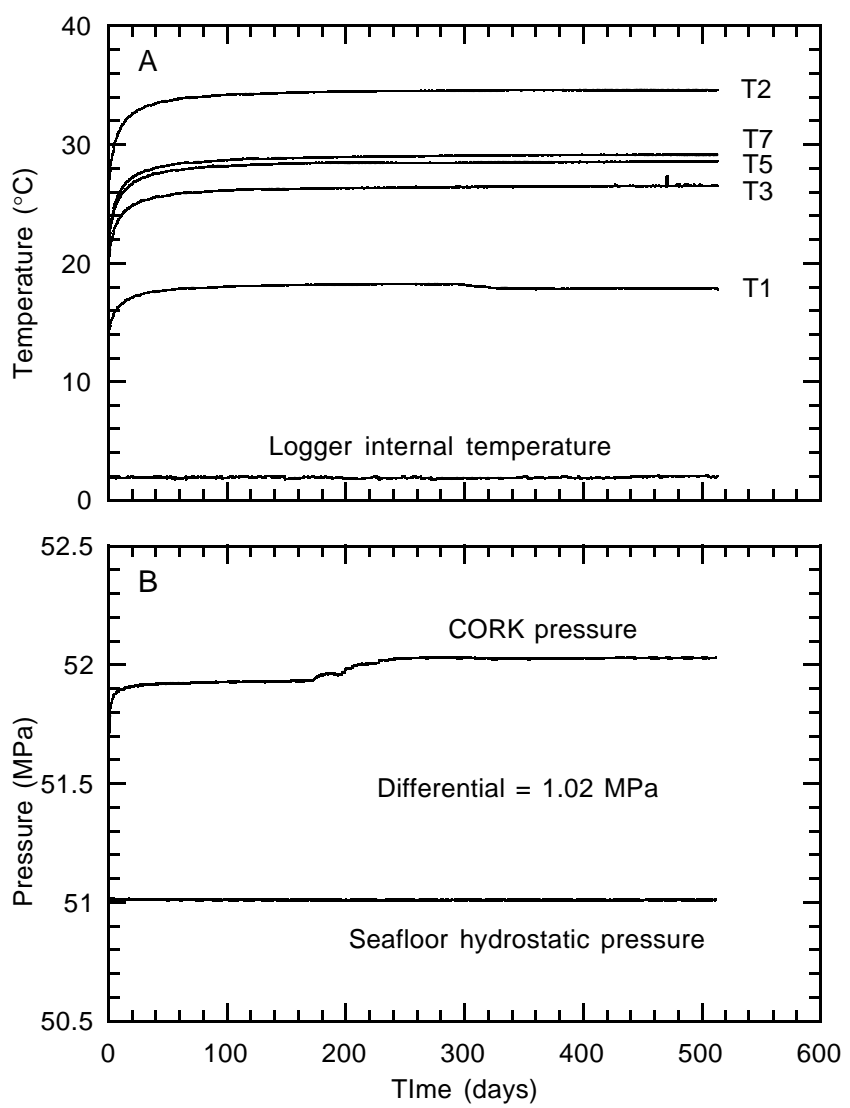

Figure 3. Long-term records of temperatures (A) and pressures (B) measured in Hole 949C.

décollement as well as an estimate for the magnitude of this pressure as determined with packer experiments during Leg 156 (Fisher and Zwart, Chapter 15, this volume). This value for the pressure in excess of hydrostatic is less than one-third of the predicted overburden pressure at the décollement. Based on the packer data and calculations described by Fisher and Zwart (Chapter 15, this volume), the bulk permeability at this measured fluid pressure would be $10^{-15}$ to $10^{-16} \mathrm{~m}^{2}$, so significant fluid flow in the décollement at Hole $949 \mathrm{C}$ is not to be expected at present.

One aspect of the pressure data provides perhaps the only suggestion for any transient fluid-flow event at Hole 949C during the recording period: this is the transient rise in pressures from 170 to 250 days after deployment (Fig. 5), when the overpressure rose in an irregular step-wise fashion from a plateau of $0.9 \mathrm{MPa}$ to a stable value of 1.02 $\mathrm{MPa}$. This might be interpreted as a minor fluid flow event, although no simultaneous indication of flow was registered in thermistor temperatures. Given the volume of the isolated borehole $\left(\approx 95 \mathrm{~m}^{3}\right)$ and typical seawater compressibility, an addition of only $5 \mathrm{~L}$ of fluid into the borehole could account for the observed pressure rise, and such a minor flux of fluid into the hole would not be expected to produce a registrable thermal anomaly. The compressibility of the sediment frame in the surrounding formation, however, probably is significantly greater than that of seawater (Taylor and Leonard, 1990), and the addition of a much larger volume of fluid to the surrounding formation is required to account for the pressure rise seen at the CORK. Nevertheless, as long any associated fluid flux is subhorizontal, no significant thermal transient would be expected in the hole.

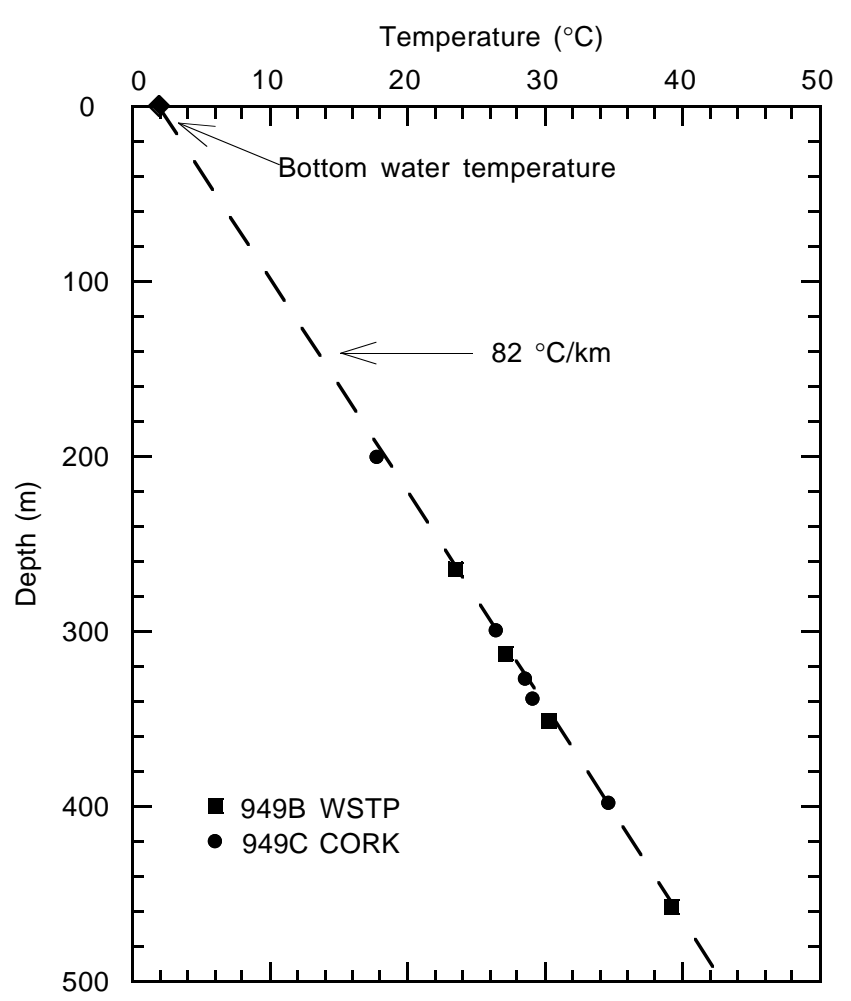

Figure 4. Downhole profile of CORK temperatures in Hole 949C and temperatures measured during Leg 156 with the WSTP (water-sampling temperature and pressure tool) in Hole 949B.

\section{Attenuation and Phase of Tidal Signal}

As noted above, the measured overpressure in Hole 949C was very stable after 250 days. The tidal signal seen in the sealed hole had near-full amplitude and little phase lag compared to the reference signal from a seafloor gauge outside the CORK seal (Fig. 6). The values of the attentuation $(\sim 0.85)$ and phase lag $(\sim 15 \mathrm{~min})$ of the tidal signal remained constant throughout the 512-day recording period. The phase lag is dispersive, with the dominant diurnal period signals (O1 and K1) lagging the seafloor tide by $4^{\circ}$, and the dominant semidiurnal signals (M2 and S2) lagging by $6^{\circ}$. The stability in the overpressure value and the attenuation and phase lag of the tidal signal attest to the robust seal at both the CORK and casing.

The attenuation and phase lag of the tidal signal in the subsurface depend in a complicated way on elastic and fluid-transport properties of the sediments (Wang and Davis, 1996). The results at Hole 949C are consistent with the nature of the muddy and porous sediments in the Barbados accretionary prism and the inferred hydrologic structure. The attenuation to $85 \%$ of the seafloor tidal loading is consistent with that expected for sediments with porosities of about $60 \%$. The phase lag requires a nearby contrast in the modulus of the sediments, with a mechanically weak zone above or below the screened interval having a lower bulk modulus. This contrast in properties could be a manifestation of the lithologic boundary associated with the décollement zone, the bifurcated nature of the décollement at the site, or a thick zone of sediment with excess porosity overlying the décollement. The last was apparent from LWD data at Sites 947 and 948 (Moore et al., 1995), but could not be resolved at Site 949 with poor core recovery and no logs. For comparison, the tidal signal in the 


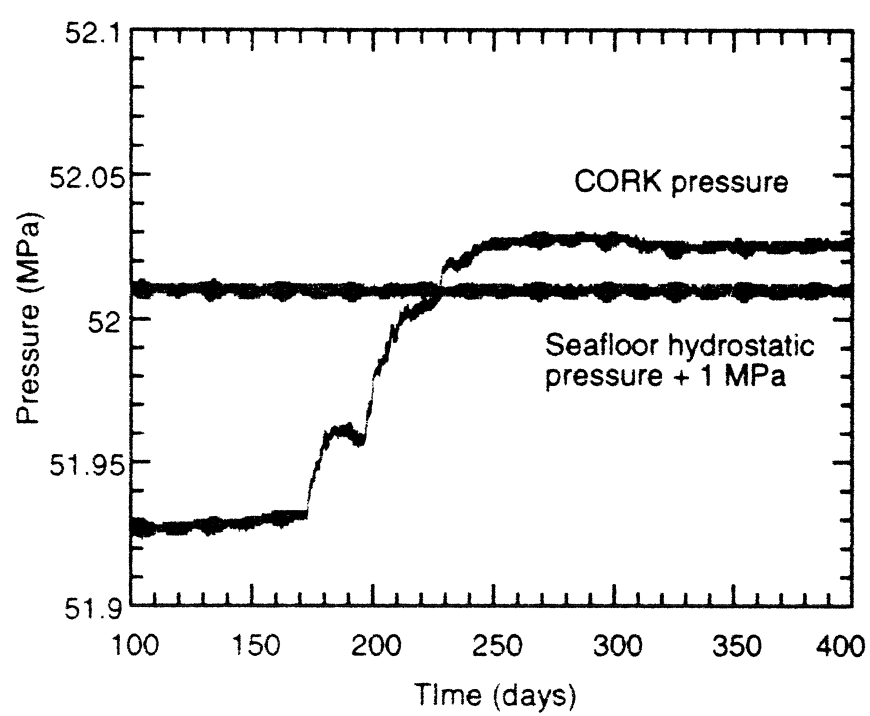

Figure 5. Expanded view of the step-wise pressure increase observed in Hole 949C 170-250 days after deployment of the CORK.

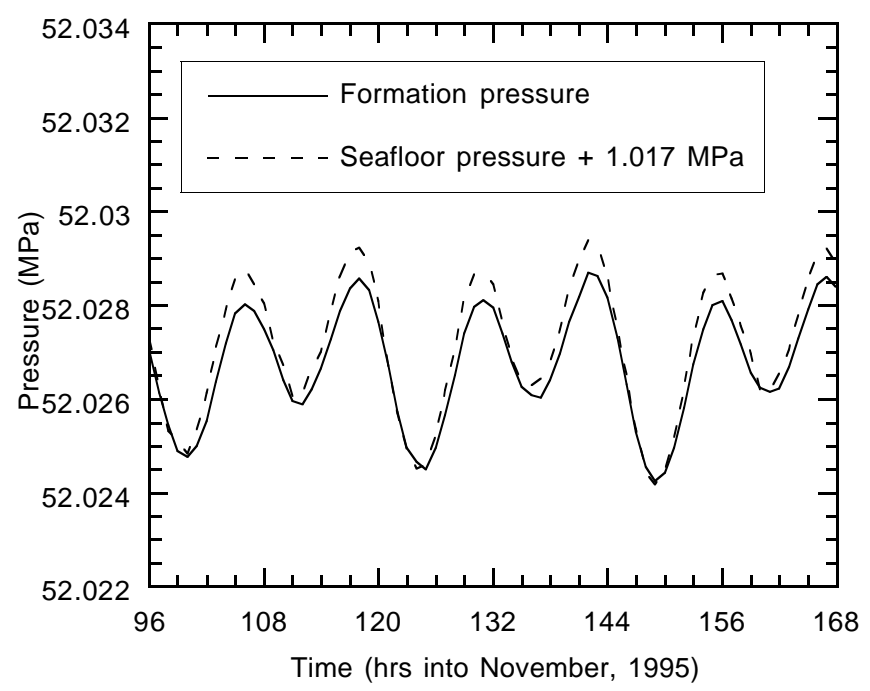

Figure 6. Comparison of the tidal signals recorded with pressure gauges inside (solid line) and outside (dashed line) the seal in Hole 949C. Attenuation of the tidal signal inside the seal is about 0.85 , and the phase lag is about $15 \mathrm{~min}$. This segment is representative of the entire 512-day recording period (i.e., attenuation and phase lag do not change during the recording period).

CORK deployed in Hole 892B on the Cascadia accretionary prism was much more strongly attenuated and actually led the seafloor tidal signal (Davis et al., 1995), probably because the sediments are sandier, more cemented, and contain free gas in the zone between the perforated interval and an overlying bottom-simulating reflector.

\section{CONCLUSIONS}

Despite a very difficult deployment, data recovered during the ODPNaut expedition indicated that the CORK experiment at Hole 949C worked very well for the first 512 days after deployment.
Downhole temperatures were quite stable, equilibrating within a few months of deployment of the CORK to values consistent with the linear gradient of $82^{\circ} \mathrm{C} / \mathrm{km}$ measured during Leg 156 in the nearby Hole 949B. Pressures measured immediately below the CORK seal indicate that fluid pressures in the décollement stabilized at a value of $1.02 \mathrm{MPa}$ above hydrostatic, less than one-third of the overburden value. The stability and magnitude of this value provide little evidence for transient fluid flow processes of the type thought to dominate the hydrology of fine-grained accretionary prisms like the Barbados accretionary prism. This is not entirely unexpected, however, as the periodicity of such transient processes is probably greater than the 512-day data period reported here. Although the apparent bulk permeability within the formation surrounding Hole 949C is low at present, it may increase when and if pressure rises in the future, more readily allowing transient fluid flow. The batteries in the data logger should allow another year or two of data logging, with a backup memory battery preserving any logged data for several years. Thus, the CORK experiment in Hole 949C was left in place, logging continuous data until some future data recovery exercise: perhaps those data will provide more conclusive constraints on transient fluid flow processes at the Barbados accretionary prism.

\section{ACKNOWLEDGMENTS}

We gratefully acknowledge the expertise and invaluable contributions of T. Pettigrew, R. MacDonald, and R. Meldrum for CORK engineering development, instrument construction, and shipboard deployment. We thank the captains and crews of the JOIDES Resolution and Nadir, as well as the pilots of the submersible Nautile. We also thank the entire scientific party of Leg 156, particularly the cochief scientists, Y. Ogawa and T. Shipley, for their support of the time and resources required to deploy the two CORK experiments. Financial support for this research was provided by the Ocean Drilling Program, the Geological Survey of Canada, JOI/USSSP (for ATF), and the National Science Foundation through Grants OCE9301995 and OCE-9415924.

\section{REFERENCES}

Bangs, N.L.B., Shipley, T.H., and Moore, G.F., 1996. Elevated fluid pressures and fault zone dilation inferred from seismic models of the northern Barbados Ridge décollement. J. Geophys. Res., 101:627-642.

Davis, E.E., Becker, K., Pettigrew, T., Carson, B., and MacDonald, R., 1992. CORK: a hydrologic seal and downhole observatory for deep-ocean boreholes. In Davis, E.E., Mottl, M.J., Fisher, A.T., et al., Proc. ODP, Init. Repts., 139: College Station, TX (Ocean Drilling Program), 43-53.

Davis, E.E., Becker, K., Wang, K., and Carson, B., 1995. Long-term observations of pressure and temperature in Hole 892B, Cascadia accretionary prism. In Carson, B., Westbrook, G.K., Musgrave, R.J., and Suess, E. (Eds.), Proc. ODP, Sci. Results, 146 (Pt. 1): College Station, TX (Ocean Drilling Program), 299-311.

Hubbert, R., and Rubey, J., 1959. Role of fluid pressures in mechanics of overthrust faulting, Part 1. Geol. Soc. Am. Bull., 70:115-166.

Knipe, R.J., Agar, S.M., and Prior, D.J., 1991. The microstructural evolution of fluid flow paths in semi-lithified sediments from subduction complexes. Philos. Trans. R. Soc. London A, 335:261-273.

Moore, J.C., Shipley, T.H., Goldberg, D., Ogawa, Y., Filice, F., Fisher, A., Jurado, M.-J., Moore G.F., Rabute, A., Yin, H., Zwart, G., and Brückmann, W., 1995. Abnormal fluid pressures and fault zone dilation in the Barbados accretionary prism: evidence from logging while drilling. Geology, 23:605-608.

Screaton, E.J., Carson, B., and Lennon, G.P., 1995. Hydrogeologic properties of a thrust fault within the Oregon Accretionary Prism, J. Geophys. Res., 100:20025-20036.

Shipboard Scientific Party, 1995. Site 949. In Shipley, T.H., Ogawa, Y., Blum, P., et al., Proc. ODP, Init. Repts., 156: College Station, TX (Ocean Drilling Program), 193-257. 
Shipley, T.H., Moore, G.F., Bangs, N.L., Moore, J.C., and Stoffa, P.L., 1994. Seismically inferred dilatancy distribution, northern Barbados Ridge décollement: implications for fluid migration and fault strength. Geology, 22:411-414.

Shipley, T.H., Ogawa, Y., Blum, P., et al., 1995. Proc. ODP, Init. Repts., 156: College Station, TX (Ocean Drilling Program).

Taylor, E., and Leonard, J., 1990. Sediment consolidation and permeability at the Barbados forearc. In Moore, J.C., Mascle, A., et al., Proc. ODP, Sci. Results, 110: College Station, TX (Ocean Drilling Program), 289-308.

Vrolijk, P., Fisher, A., and Gieskes, J., 1991. Geochemical and geothermal evidence for fluid migration in the Barbados accretionary prism (ODP Leg 110). Geophys. Res. Lett., 18:947-950.
Wang, K., and Davis, E.E., 1996. Theory for the propagation of tidally induced pore pressure variations in layered subseafloor formations. $J$. Geophys. Res., 101:11483-11495.

Date of initial receipt: 19 April 1996

Date of acceptance: 9 July 1996

Ms 156SR-031 